\title{
Delivering equality: equality mainstreaming and constitutionalisation of socio-economic rights
}

\author{
DR ANNE SMITH \\ Lecturer, Transitional Justice Institute, University of Ulster \\ and \\ EITHNE MCLAughLIN*
}

Professor of Social Policy, Queen's University Belfast and Coordinator of the Equality and Social Inclusion in Ireland Project

\section{Introduction}

$\mathrm{T}$ This article examines the role (if any) of law in the promotion and protection of equality. It frames its analysis against the backdrop of recent equality developments and proposals in the context of Northern Ireland. Our particular purpose is to address the question: are equality mainstreaming and the constitutionalisation of socio-economic rights viable tools to address inequality? These two legal tools are recognised as forming only parts, albeit highly important parts, of a bigger equality jigsaw. Constraints of space mitigate against examination of the other pieces of the jigsaw in this article. ${ }^{1}$

Regarding equality mainstreaming, we examine the operation of the equality mainstreaming model that has been adopted in Northern Ireland, most notably s. 75 of the Northern Ireland Act 1998 (the 1998 Act). In respect of constitutionalism, although

* Before completing this article, Eithne, one of the co-authors, died. Finishing it in Eithne's absence was very difficult and I hope that the final article, which is dedicated to her memory, is a fitting tribute to her. I would like to thank Eithne's husband, Pat, for his kind offer of support and assistance. Thanks are also due to Christine Bell and Fionnuala Ni Aolain for their helpful comments on earlier drafts. A special thanks goes to Mary O'Rawe for all her help. Responsibility for the views expressed and for any errors that may remain are those of the authors. Interview quotations are from interviews conducted by Anne Smith, the late Stephen Livingstone and Rachel Murray as part of a project funded by the Nuffield Foundation, "Evaluating the Effectiveness of National Human Rights Institutions: The Northern Ireland Human Rights Commission with comparisons from South Africa", February 2005. Although this article draws upon the interviews conducted for that research, the views in the article are those of the present authors alone. Similarly, the article draws on the independent element of the operational review of the statutory equality duty undertaken by Neil Faris and Eithne McLaughlin in 2004 for the NIO but does not represent the views of any parties other than the authors named.

1 This would include, inter alia, examination of the Human Rights Act 1998 (in particular, the restricted scope of Article 14 of the European Convention on Human Rights), a review of administrative law with the uncertain status of equality as a principle, the proposed Single Equality Bill for Northern Ireland, the Equality Bill 2009 for Great Britain, Targeting Social Need (TSN), the New TSN and now the anti-Poverty Strategy, proposals on equality law reform by the ECNI to the OFMDFM ("Proposals for legislative reform", February 2009) and a review of the Race Relations Order (NI) 1997. 
Northern Ireland has been provided with a "constitutional moment"2 through the Good Friday/Belfast Agreement (the Agreement), ${ }^{3}$ as a corollary of which the constitutional protection of social and economic rights ${ }^{4}$ became more fully politically achievable, at the time of writing, constitutionalisation has yet to occur. ${ }^{5}$ Consequently, we draw upon experience from other jurisdictions that have constitutionalised social and economic rights, most notably South Africa, to help reach a conclusion on the second route's capacity to deliver equality. ${ }^{6}$ Having taken into account the strengths and weaknesses of the South African experience, as the precise model of protecting social and economic rights in a Bill of Rights for Northern Ireland has yet to be determined, the article is intended to contribute to and inform the present discussion in Northern Ireland and in other jurisdictions currently in the process of constitutionalising socio-economic rights. In so doing, the article stands at the interface of academic praxis with real policy issues.

Juxtaposing these two "routes to equality" in itself provides a good illustration of the necessity of adopting a multi-layered, holistic approach to equality and the inefficacy of relying solely on litigation and the "rights discourse" or mainstreaming alone to deliver societal equity. Combining (examination of) both tools demonstrates the utility of sometimes having a legal framework that does not automatically resort to litigation and the need to sometimes "take a step outside of" the rights discourse and to gain a remedy within the political domain. Equally, it demonstrates the necessity of sometimes "taking a step inside" the rights discourse and having the ability to pursue litigation where political and related enforcement mechanisms may be insufficient. This is particularly the case when the political remedies and/or enforcement mechanisms are limited, especially for the most vulnerable groups in society who are not well represented in the democratic process and whose voices may not otherwise be heard. By adopting a "both and" rather than "either/or"

2 This term is borrowed from Nolutshungu who identified two essential elements within a constitutional idea: that of a constitutional moment and that of a constitutional function. The constitutional moment is the transition or the new beginning which is more concerned with reaching a deal between the parties and the need to secure accommodation of all the parties' interests rather than focusing on the constitutional function, the construction of a well-functioning constitutional structure. See SC Nolutshungu, "The constitutional question in South Africa" in I Shivji (ed.), State and Constitutionalism: An African debate on democracy (Sapes Trust (Southern Africa Political and Economic Series) 1991).

3 "Agreement reached in the multi-party negotiations Cm 3883" (1998) 37 ILM 751. The Agreement resulted from the talks in Northern Ireland in 1998 which produced a blueprint for how future relationships within and between the Republic of Ireland, Northern Ireland and the United Kingdom should be developed.

4 Social and economic rights refers to rights such as the right to health, right to housing, right to an adequate standard of living, right to education and so on.

5 We write in February 2010. Under Strand 3, para. 4 of the Human Rights section of the Agreement, the NIHRC was given the task of consulting and advising the British government on the content of a Bill of Rights for Northern Ireland. In December 2008, the NIHRC submitted its advice, "A Bill of Rights for Northern Ireland: advice to the Secretary of State for Northern Ireland", 10 December 2008, available at www.nihrc.org/dms/data/NIHRC/attachments/dd/files/51/A_Bill_of_Rights_for_Northern_Ireland_\% 28December_2008\%29.pdf. Two draft Bills of Rights preceded the publication of the 2008 report: NIHRC, "Making a Bill of Rights for Northern Ireland. a consultation by the Northern Ireland Human Rights Commission" (September 2001) and "Progressing a Bill of Rights for Northern Ireland: an update" (April 2004). The NIO published its response to the NIHRC's advice on 30 November 2009; NIO, "A Bill of Rights for Northern Ireland: next steps", consultation paper, November 2009, available at www.nio.gov.uk/consultation_paper_-_a_bill_of_rights_for_northern_ireland_next_steps.pdf. The NIHRC recently published its response to the NIO's consultation paper on 17 February 2010, NIHRC, "A Bill of Rights for Northern Ireland: next steps", response to the Northern Ireland Office, February 2010, available at www.nihrc.org/dms/data/NIHRC/attachments/dd/files/71/Response_to_NIO_consultation_on_a_ Bill_of_Rights_for_Northern_Ireland_(February_2010).pdf. These documents will be discussed further.

6 The authors are cognisant of the close relationship between an equality right and socio-economic rights. Due to space constraints, the primary focus is on socio-economic rights. 
approach, this article adds a more nuanced perspective to the ongoing debate on the achievement and delivery of equality. While there has been much written on mainstreaming and the recognition and enforcement of social and economic rights as individual issues, ${ }^{7}$ few, if any, scholarly works examine mainstreaming and constitutional protection in conjunction with each other. This article seeks to fill that gap and adds to the nascent literature on both mainstreaming and constitutional protection/review of social and economic rights.

For conceptual clarity and coherence of argumentation, we first consider what we mean by the terms "equality", "mainstreaming" and "constitutionalisation" (for the purposes of this paper.) In so doing, it is important to bear in mind that what is being postulated here is not a radical or new way of thinking about these three terms. Rather, this article is part of a wider project, highlighted by others, offering a more contemporary understanding of the three concepts. Following on from this, the second part of the paper will analyse the strengths and weaknesses of both tools under consideration in terms of their capacity and potential to deliver equality. Where limitations are identified in equality mainstreaming, we examine what role, if any, the constitutionalisation of socio-economic rights might play in helping to deliver equality more effectively. Given that constitutionalisation prospects in respect of Northern Ireland are still some distance from fruition, here we supplement our analysis by drawing upon the South African model of constitutionalisation and its jurisprudence to help evaluate the capacity of constitutionally based socio-economic rights to deliver equality.

We use this comparative constitutional approach to offer the prospect of expanding our understanding of the problems and opportunities that accompany the protection of equality in contemporary Bills of Rights in the globalised world. The point is not, of course, that we can readily transfer to Northern Ireland what has happened in South Africa or elsewhere. Rather, experience elsewhere is used to help "raise or sharpen awkward questions" to facilitate those involved in the Northern Ireland Bill of Rights debate to "step back" from the immediacy of the Northern Ireland context and engage more fully in a process of reflection. The article is therefore written to provide some guidance in respect of what to do and what not to do in refining and finessing the process of constitutionalising and mainstreaming equality.

The article is unique in that while the jurisdictional focus on mainstreaming equality is primarily on Northern Ireland, Northern Ireland's experience in terms of implementing the statutory equality duties articulated in the Agreement can and has been exported to national and international levels. At the national level, despite the statement that proposals in the 1998 Partnership for Equality White Paper "relate to the particular circumstances of Northern Ireland and do not carry implications for equal opportunities and race relations strategies in the different context of Great Britain", 9 the Northern Irish statutory duty has since been

7 Regarding mainstreaming, see C McCrudden, "Mainstreaming human rights" in C Harvey (ed.), Human Rights in the Community: Rights as agents for change (Oxford: Hart 2004), available at SSRN, http://ssrn.com/abstract=568642; for information on socio-economic rights, see $\mathrm{M}$ Baderin and R McCorquodale (eds), Economic, Social and Cultural Rights in Action (Oxford: OUP 2007); N Haysom, "Constitutionalism, majoritarian democracy and social and economic rights" (1992) 8 South African Journal of Human Rights 451-63.

8 K McEvoy and R Rebouche, "Mobilizing the professions: lawyers, politics, and the collective legal conscience" in J Morison, K McEvoy and G Anthony (eds), Judges, Transition and Human Rights Cultures (Oxford: OUP 2007), p. 277.

9 Dr Mo Mowlam's introduction to The Partnership for Equality. The government's proposals for future legislation and policies on Employment Equality in Northern Ireland, White Paper (1998) available at www.ccruni.gov.uk/equality/ docs/pfe98.htm\#intro. 
used as a model for the development of positive duties and mainstreaming practices in Great Britain in the Race Relations Act 2000 (RRA) and the Disability Act 2005. In April 2007, a positive duty in respect of gender equality was introduced and as part of a future Single Equality Act, the Discrimination Law Review considered the introduction of a generic positive duty in Britain. ${ }^{10}$ The Northern Ireland case is also influential internationally, for example, in the ongoing equality mainstreaming review being undertaken as part of the development of the Equality Commission for Northern Ireland's (ECNI) anti-discrimination programme. ${ }^{11}$

\section{Definitional issues: equality, mainstreaming and constitutionalisation}

\section{EQUALITY}

The concept of equality has generated debate amongst moral and legal philosophers for centuries. Equality can mean anything and everything. It has meant different things to different people producing a situation in which equality can be described both as a word "in which a number of differing conceptions have always been in competition"12 and as "an extremely dynamic principle . . . offering wide scope for divergent interpretations of its content". ${ }^{13}$ It thus belongs to that category of words with both a vague conceptual meaning and a rich emotive meaning, with the conceptual meaning being subject to constant redefinition. ${ }^{14}$ It is therefore unsurprising that, in the literature, equality proves an "elusive notion", ${ }^{15}$ whereby "conceptions of equality are notoriously protean". ${ }^{16}$ Broadly speaking, a distinction is frequently drawn between formal and substantive concepts of equality.

\section{Formal equality}

Essentially, formal equality requires that all persons who are in the same situation be accorded exactly the same treatment and that people should not be treated differently because of arbitrary characteristics such as religion, race or gender. ${ }^{17}$ This formulation resonates with the original Aristotelian conception of equality, that like cases should be treated alike. It is the least formally contentious and therefore less technically problematic concept from a black letter law point of view, yet it fails to recognise that it is only in certain

10 Department of Communities and Local Government, "Discrimination law review. a framework for fairness: proposals for a Single Equality Bill for Great Britain”, a consultation paper (June 2007), available at www.communities.gov.uk/documents/corporate/pdf/325332.pdf. The Government Equalities Office issued "The Equality Bill - government response to the consultation" (July 2008), setting out its proposals for an Equality Bill for Great Britain which was introduced in the House of Commons on 24 April 2009 and became an Act of Parliament on 8 April 2010.

11 The ECNI is the body that was set up under the Agreement to oversee the implementation and enforcement of s. 75. The ECNI published its final report on s. 75 in November 2008, see "Section 75: keeping it effective - reviewing the effectiveness of Section 75 of the Northern Ireland Act 1998”, Final Report, November 2008. This report and the ECNI's role will be discussed further below.

12 C McCrudden, "Institutional discrimination" (1982) 2(3) Oxford Journal of Legal Studies 303-69, at 346.

13 J Schwarze, European Administrative Law (London: Sweet \& Maxwell 1992), p. 546.

14 CL Stevenson XLVII, Mind (1938), p. 331, cited by C McCrudden in "Institutional discrimination" (1982) 2(3) Oxford Journal of Legal Studies 303-67, at 346.

15 N Bamforth, "Conceptions of anti-discrimination law" (2004) 24(4) Oxford Journal of Legal Studies 693-716, at 704 .

16 D Harris, "Equality, equality rights and discrimination under the Charter of Rights and Freedoms" (1987) 21 University British Columbia Review 389-428, at 390.

17 This version of equality is described by McCrudden as equality as "individualized justice", C McCrudden, "Theorising European equality law" in C Costello and E Barry (eds), Equality in Diversity (Dublin: Irish Centre for European Law/Ashfield Publications 2003), pp. 20-1. 
contexts that these characteristics are irrelevant ${ }^{18}$ and that same treatment will result in equitable treatment. It is somewhat invidious and counter-intuitive to promote and require formally equal treatment, if people, partly through starting from very different places to which law affects a considered blindness, ultimately do not end up equally situated. For instance, if black and white citizens are required to be treated the same on the grounds that they are, for all relevant purposes, "alike", a virtue is somehow made of ignoring very real differences in income, housing and basic health and educational levels. This, in itself, will have an adverse impact upon the opportunities for advancing black and other disadvantaged citizens. As O'Cinneide states "while being superficially attractive, [equal treatment] ignores the specific contexts in which real individuals are situated". ${ }^{19}$ Formal equality therefore is a negatively based concept and equates to fairly limited and reactive discrimination rather than anything more far-reaching.

\section{Substantive equality}

The authors' preferred concept of equality moves away from this limited and symmetrical approach to one which is concerned with making sure that laws or policies do not impose subordinating treatment on groups already suffering social, political or economic disadvantage. The focus is on the group and on the impact of the law on its social, economic or political conditions. It recognises that sameness of treatment can reinforce inequality and, in certain circumstances, equality (of result) actually requires differential or preferential treatment. This focus on differential treatment orients the right to equality from a negatively oriented right of non-discrimination to a positively oriented right to substantive equality. This concept is proactive, requiring the state to take positive measures to promote equality. This positive and "thick" concept of equality requires the state to adopt an asymmetrical and substantive approach and to facilitate or provide so as to create "equality of opportunity". However, the ability of "equality of opportunity" to deliver a stronger and more comprehensive guarantee of equality depends on the meaning given to this concept. This particular discussion is extremely relevant to the discussions on mainstreaming and constitutional protection of socio-economic rights as equality of opportunity is a principal concept underpinning the effective operation of both legal tools. The definition applied to this term, will, of necessity, determine the ability, or inability, of both tools to deliver a substantive notion of equality.

\section{Equality of opportunity}

The potential of "equality of opportunity" to facilitate equity of approach and result depends on its categorisation as either "timid" or "robust". A timid approach is about creating a common starting point for treatment by removing illegitimate criteria, while ignoring the varying ability of different groups to compete once fair procedural requirements are in place. Considerations affecting ability to avail of the opportunities on offer is underplayed in such a scenario. Hepple argues that equality of opportunity in this sense operates as a procedural requirement that is not concerned with results. Meanwhile, it leaves unchallenged and unexamined notions of "merit" that may be stacked against underprivileged groups. ${ }^{20}$

18 S Fredman, Discrimination Law (Oxford: OUP 2002), pp. 7-10.

19 C O'Cinneide "Making the use of positive equality duties: the UK experience" in Costello and Barry, Equality in Diversity, n. 17 above, p. 78.

20 B Hepple, "Have twenty-five years of the Race Relations Act in Britain been a failure?" in B Hepple and E Szyszczak (eds), Discrimination: The limits of the law (London: Mansell 1992), ch. 2. 
In contrast, a more robust notion of equality of opportunity is concerned with the members of a group who have historically been disadvantaged enjoying equality in real conditions, including economic conditions. This stronger and more ambitious concept is about creating opportunities enabling and empowering people to have options and make choices. This more thorough conceptualisation of equality and all that it entails aims towards and is guided by what is referred to in the literature as the group justice theory or equality of results. ${ }^{21}$

\section{Equality of results/group justice model}

Under this theory, equality is based on the idea of delivering equal distribution of goods and opportunities to economically or otherwise disadvantaged groups to ensure that the result is equal in real terms. This is achieved by prohibiting practices which cannot be objectively justified and have the effect of disproportionately disadvantaging a particular group, directly or indirectly. Equality of results thus recognises that apparently identical treatment can, in practice, reinforce inequality because of past or ongoing discrimination. ${ }^{22}$ The group justice model not only aims to redress past injustices but also seeks to achieve an equal distribution of social goods. As such, equality becomes about securing greater economic and other forms of justice between groups distinguished by access to goods and has therefore been referred to as "material equality or equality of resources". 23

The authors argue that the approach taken to equality in Northern Ireland, South Africa or anywhere, where inequality was/is a dominant issue, should be one that is significantly redistributive in its aims. As McCrudden argues, redistribution is essentially the desired result of a good equality mainstreaming process. ${ }^{24}$ The authors also opine that the same argument applies to the constitutional protection of economic and social rights. If a society is to be more equal and fairer, it is important that the reallocation of resources is directed to the most vulnerable in society. However, as far as the Northern Ireland model of mainstreaming is concerned, a budgetary component is notable for its absence. For this reason, whereas public bodies may well discover through Equality Impact Assessments (EQIAs) (an issue we return to later) that their policies or actual service delivery are causing adverse effects on certain groups, uncertainty arises as how to secure the resources to address those issues. This uncertainty, we argue, can be potentially limited or reduced if the state and public bodies are under a constitutional duty to "progressively realise" the state's obligation to ensure that resources are in place to help reduce socio-economic inequalities. We return to this issue shortly.

An important aspect of equality of results is the adoption of "group" focused measures such as preferential treatment/affirmative action. These might include using quotas to improve the under-representation of certain groups in particular areas of the employment sector or taking proactive measures actively to address the legacy of socio-economic problems and group inequalities. Due to the proactive nature and the need to implement positive legislative and programmatic measures to realise the substantive vision of equality, these approaches are perceived by some as problematic and coming into sharp conflict with

21 See McCrudden, "Theorising European equality law", n. 17 above, pp. 22-8, and A Morris, "On the normative foundations of indirect discrimination law: understanding the competing models of discrimination law as Aristotelian forms of justice" (1995) 15(2) Oxford Journal of Legal Studies 199-228.

22 S Fredman, Discrimination Law, n. 18 above, p. 11.

23 R Dworkin, Sovereign Virtue: The theory and practice of equality (Cambridge, Mass: Harvard UP 2000), p. 131.

24 C McCrudden, "Mainstreaming equality in Northern Ireland 1998-2004: a review of issues concerning the operation of the equality duty in Section 75 of the Northern Ireland Act 1998", in N Faris and E McLaughlin (eds), The Section 75 Equality Duty: An operational review (Belfast: NIO 2004), vol. 2, p. 23. The report is to be found at www.nio.gov.uk/sect_75_equality_duty_an_operational_review_volume_2.pdf. 
the equal (as same) treatment principle. ${ }^{25}$ This school of thought is in line with what has been described as the "individual justice" 26 model of equality and maps on to the "timid" notion of equality of opportunity described earlier. Proponents of the individual justice model are not concerned about groups so much as what is right in an individual case. This model posits the state's role is to reduce discrimination by eliminating any use of personal characteristics that might have harmful implications for individuals and which are actually irrelevant to an individual's entitlement to a social good or benefit. Emphasis is placed on securing fairness for the individual. As such, affirmative action is often characterised as running counter to the spirit of an equality provision and as a form of "reverse discrimination" - a practice of favouring those discriminated against in the past and discriminating against those favoured in the past.

The authors along with several others ${ }^{27}$ have a number of difficulties with this approach and argue that, rather than viewing affirmative action as an exception to equality principles, preferential treatment of disadvantaged groups is actually a core part of the right to equality. This is in line with the substantive understanding of equality which views equality as a longterm goal to be achieved through measures and programmes aimed at reducing current inequality. This understanding views discrimination as so deep and entrenched against certain groups, such as women, black Americans or black South Africans, that it has become institutionalised and the simple identification and removal of formal discriminatory barriers will not suffice to provide redress. What is required is more than simple prohibition of unequal treatment, but a positive obligation on the state to confer benefits on the group concerned to remedy past injustices against the group. Thus, what could be construed as directly discriminatory measures which favour relatively disadvantaged groups at the expense of those who are relatively well off will not constitute discrimination as the consequence of such measures, in the end, tend towards a more equal society. ${ }^{28}$ Affirmative action in this view is therefore a manifestation, not a limitation of equality. As Sachs convincingly argues, a Bill of Rights without a constitutionally structured programme of affirmative action, especially in countries emerging from violent conflict where inequality was at the core of that conflict, is "meaningless". ${ }^{29}$ He continues:

this deprives the Bill of Rights of its true potential as a major instrument of ensuring a rapid, orderly, and irreversible elimination of the great inequalities and injustices left behind by apartheid. ${ }^{30}$

Those who have benefited from the past regime should not be able to come to court to complain that their constitutional rights are being violated because there are special programmes to deal with homelessness amongst blacks, or Catholics or whoever may be the least well off. A constitutional commitment to affirmative action establishes the goal of equal chances for all. It puts the achievement of equal rights firmly on the agenda and forces the whole of society to face up to the consequences of years of accumulated discrimination. It does so by establishing criteria and mechanisms for monitoring progress

25 MB Abram, "Affirmative action: fair shakers and social engineers” (1986) 99 Harvard Law Review 1312-46.

26 McCrudden, “Theorising European equality law”, n. 17 above, pp. 22-8.

27 A Sachs, "Affirmative action and good government" in P Hugo (ed.), Redistribution and Affirmative Action: Working on the South African political economy (Pretoria: Southern Book Publishers 1992); and McCrudden, "Theorising European equality law", n. 17 above, pp. 22-8.

28 An example would be admission criterion to a certain occupation favouring applicants from a particular disadvantaged group who have not been able to enter into a profession due to past discrimination over other applicants who are less disadvantaged.

29 A Sachs, Protecting Human Rights in a New South Africa (Oxford: OUP 1991), p. 12.

30 Ibid. 
and facilitates greater inclusiveness in the institutions of government. When these are more representative, previously alienated people are more likely to feel that these are "their police force, their courts". Affirmative action is a crucial mechanism whereby Bills of Rights can be potentially harnessed as tools for correcting the past by ensuring that social goods are redistributed to benefit those most in need - the marginalised. ${ }^{31}$

\section{MAINSTREAMING}

Mainstreaming represents a particular vision of how equality can be achieved. It is a model that aims to bring equality from the "margins" to the "mainstream" 32 by placing equality issues at the centre of decision making. This is achieved by ensuring that an equality perspective is incorporated in all policies and procedures and at all stages by the actors involved in decision making around these issues. Mainstreaming requires the reorganisation, improvement, development and evaluation of policy processes. ${ }^{33}$ Accordingly, processes are designed to ensure equality issues cannot be sidelined. Rather, mainstreaming equality should result in the infusion of equality into the design and delivery of processes and policy outputs in all government departments. The distinguishing features of this approach to equality are proactivity and positivity as opposed to reactivity and negativity - features synonymous with the traditional approach of anti-discrimination law. In other words, rather than waiting for an equality violation to occur and then taking remedial action, mainstreaming is anticipatory and requires positive action from all relevant actors to ensure that those who will be most affected by the decision are facilitated to be involved at the early stages of drafting policies. Participation and involvement from those on the ground is deemed key to ensure equality issues are effectively mainstreamed. Other key aspects of this process include appropriate institutional arrangements; awareness raising; training and expertise; mainstreaming tools; reporting (and effective enforcement) mechanisms; "commitment from the top"; incentives to build "ownership" and the securing of necessary resources. ${ }^{34}$ As we will see shortly, due to what we term "creative minimisation" of some of these factors, the Northern Ireland experience of equality mainstreaming has fallen well short of its goal. Before exploring these issues, the following section provides an overview of s. 75 requirements and processes.

\section{Northern Ireland model of mainstreaming}

Section 75 of the 1998 Act is the legislative equality mainstreaming tool for Northern Ireland. Section 75(1), commonly referred to as the statutory equality duty, requires

31 While supportive of affirmative action, the authors also recognise the tension between the notion of equality as economic redistribution and equality as identity. This raises the thorny issue of the relationship between individual and group equality - the right of an individual not to be treated as a member of a distinctive group against their will and at the same time ensuring the group as a group enjoys equality, by adopting groupfocused measures such as preferential treatment/affirmative action. Due to space constraints, the potential conflict between the notion of equality as economic redistribution and equality as identity will not be addressed as one of the authors has already examined these issues in another article, A Smith, "Constitutionalisng equality: the South African Experience" (2008) 9(4) International Journal of Discrimination and the Law 201-49. See also C McCrudden, "Consociationalism, equality and minorities in the Northern Ireland Bill of Rights debate: the role of the OSCE High Commissioner on National Minorities" in Morison et al., Judges, n. 8 above, ch 15.

32 A phrase used by Mageean and O'Brien; P Mageean and M O’Brien, "From the margins to the mainstream: human rights and the Good Friday Agreement” (1999) 22 Fordham International Law Journal 1499-538.

33 This definition of mainstreaming is drawn upon the Council of Europe, Rapporteur Group on Equality between Women and Men, “Gender mainstreaming”, GR-EG (98) 1, 26 March 1998, p. 6.

34 P Chaney and T Rees, "The statutory equality duty in Northern Ireland in international perspective", in Faris and McLaughlin, The Section 75 Equality Duty, n. 24 above, p. 23. 
designated public authorities to have "due regard to the need to promote equality of opportunity":

- between persons of different religious belief, political opinion, racial group, age, marital status, or sexual orientation;

- between men and women generally;

- between persons with a disability and persons without; and

- between persons with dependants and persons without.

The Northern Ireland model has been described as the "most innovative" 35 measure of this nature to date as it stands out from several other attempts at equality mainstreaming. In brief, the most "innovative" aspects of this provision are equality schemes, screening and impact assessments, and enhanced (potential for) participation. ${ }^{36}$

\section{Unique features}

\section{a) Equality schemes}

Each designated public authority must have an equality scheme in place, both as a statement of its commitment to the statutory duty, and as a plan for execution of the different aspects of that duty. This plan is submitted to the ECNI, a body established under the same Act. If the ECNI thinks it appropriate, a public authority may be required to revise its scheme. Before submitting a scheme to the ECNI, a public authority is required to consult with those likely to be affected by the scheme, to consider ameliorating policies and to publish the outcomes of these processes. The published equality schemes set out authorities' arrangements for consultation under the equality duty. Consultation with those most likely to be affected by public policy decisions is thus (in theory) placed at the heart of the statutory duties.

Having received the equality scheme from the public authority in question, the ECNI either approves it or refers it to the Secretary of State for Northern Ireland who has three options: to approve the scheme; to request the public authority to make a revised scheme; or to make a scheme for the public authority. If it is referred, the ECNI must notify the Northern Ireland Assembly. Thus, failure to mainstream appropriately results in action taking place within the political field rather than through litigation, an issue to which we shall return subsequently.

\section{b) Screening and impact assessment}

Two unique techniques underlying the Northern Ireland model are screening and impact assessment. The former requires public authorities to screen or "equality proof" new and existing policies. Where screening indicates that an adverse equality impact is possible, decision makers must then fully assess the equality impact of the policies through an EQIA and consider ameliorating policies. The requirement to consider ameliorating policies means

35 Mageean and O’Brien, "From the margins", n. 32 above, at 1524.

36 The other idiosyncrasy of the Northern Ireland model is the duty on public authorities to "have regard to the desirability of promoting good relations between persons of different religious belief, political opinion or racial group". The words "have regard" are weaker strictures than "due regard" which is included in the equality of opportunity duty. However, due to constraints of space and length, the article will not focus on the good relations duty, but primarily on the equality duty. Suffice to state that there are strong arguments for giving priority to equal opportunities. If ensuring "good relations" was given the same level of importance as equality, this could have many problematic consequences in the Northern Irish context. For example, would promoting "good relations" justify "separate but equal" policies in areas such as education, which might run counter to equality of opportunity considerations? 
that if a public authority's assessment of the impact of a policy shows possible "adverse impact" on any of the specified grounds of (in)equality, it must consider how this impact could be reduced, and whether an alternative policy or decision might lessen the adverse impact the original proposal would have had. Furthermore, the public authority should also show more generally that it considered how alternative policies and decisions might better achieve the promotion of equality of opportunity. In so doing, this model is pro-active rather than reactive as it tries to alert policymakers to potential problems before they happen. Adopting such a proactive approach and focusing on the effect of policies on equality and what steps public authorities can take to lessen the adverse impact of same falls squarely within a substantive notion of equality.

Unfortunately, no specific additional resources were allocated to public authorities to fund alternative policies or provision which would better achieve equality of opportunity. The extent to which public authorities can promote equality of opportunity thus depends in large part on the inherent equality promoting capacities of the policies themselves. In some cases, these policies and provisions are inherently productive of inequality rather than equality. ${ }^{37}$ Furthermore, not all policies are subject to screening as public authorities can "screen out" those policies and practices which they think do not need to be impact assessed. On the one hand, this is a sensible way forward as it would be unrealistic and costly to screen all policies. However, on the other hand, as McCrudden notes, some public authorities may take advantage of this approach to evade impact assessments of the most difficult issues. 38 This concern has been noted by the Children's Law Centre (CLC), Northern Ireland:

When a public body carries out a screening exercise on a policy to decide whether or not an EQIA is necessary it has often been the case that policies have been screened out where they should not have been. This is concerning as the majority of public bodies, despite a stated obligation to consult on screening, do not and there is no way of knowing that a screening decision has been made by a public authority as the process is not transparent. ${ }^{39}$

Arguably, if public authorities were under a constitutional obligation to ensure that all policies complied with fundamental principles such as equality, fairness, dignity, and respect for civil and political as well as economic and social rights, they would be obliged not to default from their basic obligation. Failure to do so could result in a court-based enforcement which public authorities would want to avoid.

This is in stark contrast to the current enforcement mechanism under s. 75 which relies on statutory protection and action taken in the political arena rather than litigation. Paradoxically, compliance with the statutory equality duty with less emphasis placed on litigation may result in public authorities taking their equality mainstreaming duties more seriously than the supposed threat of face-to-face litigation and adjudication. In this context, the outcome of the case of $\mathrm{R}$ (Kaur \& Shah) v London Borough of Ealing (hereinafter the Southall Black Sisters (SBS) case) ${ }^{40}$ is extremely relevant. Although the case concerned s. 71 of the RRA which involves "specific duties" on public authorities to promote race

37 For example, compulsory competitive tendering for ancillary services in the public sector and commissioning a mixed economy of care services.

38 McCrudden, Mainstreaming Equality, n. 24 above. To negate this problem, the ECNI in its final report on s. 75 states that where a public authority proposes, following screening, to screen out the policy, a 12-week consultation will remain a requirement. ECNI, "Section 75", n. 11 above, p. 39.

39 CLC, "Response to the Equality Commission's Consultation on its Section 75 effectiveness review", August 2007, p. 7 (on file with the authors).

40 [2008] EWHC 2062 (Admin). 
equality, ${ }^{41}$ this duty was partly modelled on s. 75 . Ealing Council had decided to withdraw funding from SBS, a specialist domestic violence centre, as it wanted to use that funding to provide cross-community support and assistance to victims of domestic violence irrespective of race. The council had carried out an initial Race Equality Impact Assessment (REIA), but a full REIA was not carried out until after the legal proceedings had begun. SBS therefore argued that the council had acted unlawfully and was in breach of its public sector race duties. Ealing Council withdrew from the case agreeing to carry out a new REIA on any new proposals. The threat of further litigation influenced the council's decision to accept it had erred in not carrying out a full REIA at the appropriate time. The outcome of the case shows how the threat of litigation can make public authorities take mainstreaming more seriously. As Lord Justice Moses stated, REIA "should be an integral part of the formation of a proposed policy, not justification for its adoption ... [The REIA] is not satisfied 'by ticking boxes', it [REIA] must be undertaken as a matter of substance and with rigour". ${ }^{42}$ This is a very powerful conclusion, a conclusion which it is doubtful would or could have been achieved under the "enforcement" mechanisms of Article 67 of the RRA or s. 75 of the 1998 Act alone. This judgment also helps to illustrate the causative relationship between mainstreaming and litigation. If public authorities do not approach EQIAs substantively and rigorously, then this is where "taking a step inside" the rights discourse can be helpful.

\section{c) Participation}

In determining whether there is a possible adverse impact, examining alternatives and considering ameliorative policies requires direct consultation with those likely to be most affected by the policies themselves. This approach allows groups, especially those who would have hitherto been excluded from decision making, to become involved in influencing governmental decisions. Thus, combining the participative approach with impact assessment contributes to the growing of deliberative and participative democracy and the introduction of new forms of governance for public services. This point is aptly summed up by Harvey:

Too many discussions of participation and deliberation fail to show how policies and institutions might be redesigned to achieve substantive gaols. Consultation can be a paper exercise regarded by government as no more than a troublesome mechanism that must be endured. The Northern Ireland provisions indicate how we might move beyond this in the sphere of equality by building processes into public decision-making and policy formulation. This is most evident in the equality field where public authorities [are] required to construct institutional mechanisms to evaluate and respond to the impact of their work on equality. ${ }^{43}$

However, like the previous two features, the impact of participation has also been negated/diluted by "creative minimisation" of the statutory duty. In other words, there has been a lack of meaningful consultation as public authorities have adopted consultation methods which have been those most convenient and least effortful for the public authorities concerned rather than those which are most successful or effective in engaging

41 S. 71(1) of the RRA states: "Everybody or other person specified in Schedule 1A or of a description falling within that Schedule shall, in carrying out its functions, have due regard to the need - (a) to eliminate unlawful racial discrimination; and (b) to promote equality of opportunity and good relations between persons of different racial groups."

$42 R$ (Kaur \& Shah) v London Borough of Ealing [2008] EWHC 2062 (Admin), paras 24 and 25.

43 C Harvey, "Governing after the rights revolution" (2000) 27 Journal of Law and Society 61-97, at 86. 
with consultee communities. ${ }^{44}$ Before further examination of these and other issues, we now turn to focus on the second piece of our jigsaw, the constitutional protection and adjudication of socio-economic rights.

\section{CONSTITUTIONAL PROTECTION AND ADJUDICATION}

Traditionally, the constitutionalisation of rights signals that such rights belong to a category of fundamental minimal entitlements that the state has to respect, protect and fulfil. ${ }^{45}$ If the state fails to adhere to these obligations, then, by virtue of constitutionalisation (if by no other means), ${ }^{46}$ individuals have the right to petition the courts on the grounds that their constitutional rights have been violated. Unlike the situation whereby these rights are secured and retained by ordinary legislation, this particular method gives the courts the power to challenge, veto and, in some instances, strike down social and other incompatible/unconstitutional legislation. As such, constitutionalised rights are directly enforceable (justiciable) through the courts.

On a number of levels, attributing the power to judges to substitute their own views for those of democratically elected representatives is deeply problematic. This is particularly the case in respect of socio-economic rights, given the redistributive element necessarily contained within these rights. Some scholars argue that, as such rights have huge monetary implications and require expenditure decisions, it is inappropriate and illegitimate for courts to determine such issues on a case-by-case basis, which will undoubtedly have knock-on effects for other governmental concerns and priorities. Such balancing, weighing and expenditure exercises are, therefore, properly the function of democratically elected parliaments ${ }^{47}$ as opposed to courts. Both legitimacy and institutional concerns are raised in the literature. For example, Waldron ${ }^{48}$ and $\mathrm{Dahl}^{49}$ individually argue that shifting the onus of interpretation and elaboration of rights away from the political forum and elected officials, where popular discussion might make a difference, into the hands of non-elected and non-accountable judges could lead to the "disabling of representative institutions", 50 displacing popular self-government ${ }^{51}$ in favour of government "by judiciary". Rather than

44 The ECNI's final report on s. 75 also found a similar finding: "public authorities have sought the views of representative organisations rather than seeking the views of the public and those directly affected by policies". ECNI, "Section 75", n. 11 above, p. 41.

45 The tripartite obligation is borrowed from H Shue, Basic Rights: Subsistence, affluence and US foreign policy (Princeton, NJ: Princeton UP 1996).

46 Ordinary legal provision may equally permit access to the courts in a variety of scenarios.

47 These are only some objections to making socio-economic rights justiciable. Due to space constraints, the article will not revisit other issues about the justiciability of social and economic rights which have already been well documented in several scholarly writings. For a general overview, see Baderin and McCorquodale, Economic, Social and Cultural Rights, n. 7 above; Haysom, "Constitutionalism", n. 7 above; M Pieterse, "Coming to terms with judicial enforcement of social and economic rights" (2004) 20 South African Journal on Human Rights 383-417.

48 J Waldron's writings include: "A right-based critique of constitutional rights" (1993) 13(1) Oxford Journal of Legal Studies 18-51; "The core of the case against judicial review" (2006) 115 Yale Law Journal 1346-406; Democracy and Disagreement (Oxford: Clarendon Press 1999); "Taking group rights carefully" in G Huscroft and P Rishworth (eds), Litigating Rights (Oxford: Hart 2002).

49 R Dahl, Democracy and its Critics (New Haven: Yale UP 1989).

50 Waldron, "A right-based critique", n. 48 above, at 28.

51 S Gardbaum, "The new commonwealth model of constitutionalism" (2001) 49 American Journal of Comparative International Law 707-60, at 740. 
facilitating governance by the people for the people, embellishing judicial authority to this degree is clearly "counter-majoritarian" 52 and, as such, can be viewed as anti-democratic.

We are not persuaded by this line of argumentation. Firstly, the case is not made out that the simple presence of a redistributive element in the enforcement of socio-economic rights is sufficient to bar their justiciability. As McKeever and Ni Aolain rightly point out, redistribution is a feature of many judicial decision-making contexts from tort damages to competition law. ${ }^{53}$ While acknowledging that the potential redistributive element for social and economic rights may be greater, the fact that the courts are already involved in a range of issues ${ }^{54}$ which have important resource implications makes their role in socio-economic cases more tenable. Secondly, the anxiety underpinning usurpation arguments is rooted in a traditional and dated understanding of the doctrine of separation of powers. According to this view, the legislature makes the law, the executive implements the law and the judiciary applies and enforces the law. We argue that this overly simplistic conventional analysis actually represents a misunderstanding of democracy in practice and does not reflect reality. Realpolitik demands countenancing and facilitating the operation of a "pragmatic mixture of functions". 55 Such "mixture" and blending of functions per se lacks purchase in arguing for the exclusion of social and economic rights from the reach of the courts, thereby reducing them to the status of poor cousins, inferior and distinguishable from civil and political rights where the court's reach is staunchly defended as key to the democratic process. This point was noted in the South African case of First Certification Judgment:

A court may require the provision of legal aid, or the extension of state benefits to a class of people who formerly were not beneficiaries of such benefits. In our view it cannot be said that, by including social and economic rights within a bill of rights, a task is conferred upon the courts so different from that ordinarily conferred upon them by a bill of rights that it results in a breach of the separation of powers ... The fact that social and economic rights will almost inevitably give rise to such implications does not seem to us to be a bar to their justiciability. 56

Recognising the justiciability of socio-economic rights does not preclude an acknowledgment that they fall along a "justiciability spectrum". ${ }^{57}$ Socio-economic rights do not have the degree of self-execution displayed by other rights. Rather an obligation is imposed on states to ensure they take steps to the maximum of their available resources, with a view to achieving progressively the full realisation of these rights by all appropriate means, including particularly the adoption of legislative and other measures. The fact that states are enjoined simply to create programmes progressively to realise socio-economic rights and to ensure that basic needs receive a degree of legislative priority dilutes a further

52 This phrase was coined by Professor Bickel and has set out the contours of the debate in A Bickel, The Least Dangerous Branch: The Supreme Court at the Bar of American politics (New Haven: Yale UP 1986). See B Friedman, "A history of the countermajoritarian difficulty: part one - the road to judicial supremacy" (1998) 73 New York University Law Review 333-433.

53 G McKeever and F Ni Aolain, "Thinking globally, acting locally: enforcing socio-economic rights in Northern Ireland" (2004) 2 European Human Rights Law Review 158-80, at 161. See also J King, "The pervasiveness of polycentricity" (2008) Public Law 101-24.

54 For example, claims in tort, equality and contract.

55 B Neuborne, "Judicial review and separation of powers in France and the United States" (1982) 57 New York University Law Review 363-442, at 370-1.

56 Ex Parte Chairperson of the Constitutional Assembly: in re Certification of the Constitution of the Republic of South Africa 19961996 (4) SA 744 (CC); 1996 (10) BCLR 1253 (CC) paras 77-8.

57 D Brand, "Introduction to socio-economic rights in the South African Constitution" in D Brand and C Heyns (eds), Socio-Economic Rights in South Africa (Pretoria: Pretoria UP Law Press 2006), p. 22. 
anxiety in respect of the implications of justiciability of social and economic rights. A demand for social and economic rights is not a demand for state handouts. On the contrary, the demand is for government to put in place special policies and, where appropriate, legislative arrangements to facilitate access to such rights. As Fabre rightly notes:

The point of having constitutional social rights protected by the judiciary is not to substitute judicial policy-making for governmental policy-making: it is to remedy violations of rights resulting from bad government policy-making. ${ }^{58}$

Rights without a remedy are simply paper rights. If a violation of socio-economic rights results in no engagement of institutional authority or enforceable sanction, such rights are rendered at a stroke both meaningless and "toothless". ${ }^{59}$ As Porter states:

The idea that you have a right but nowhere to go for a hearing or a remedy when it is violated ... really attacks the central place accorded to individual dignity and equality of citizenship and to rights holders as the "subjects" of rights. ${ }^{60}$

Viewed in this way, constitutionalisation is about providing an adjudicative forum/space for individuals or groups to hold government and others to account for actions that affect their lives. The possibility of enforcement by the courts may help deter "bad government policy-making" in the first place as government will want to avoid litigation for several reasons. Firstly, having policies and other governmental provision successfully contested in the courts sends out a negative signal at both national and international level that the government is failing to uphold its constitutional obligations, thereby placing a potentially important spotlight on government inaction or failure to follow through on its commitments. This may motivate government to address proactively the unmet needs of the most vulnerable people in society. If litigation does occur, the government and state authorities will be required to give well-reasoned, public justification for social and economic policies. Whether the court ultimately finds in favour of or rejects the government's policy, constitutionalisation helps raise the profile of the need for effective enforcement and ensures public power accountability through government "being kept on its toes" 61 as the subject of the scrutiny of justification.

Another important factor to note, and one which is demonstrated by the South African experience to date, is that the courts have potential to issue non-adjudicatory remedies as well as adjudicatory ones. In so doing, by "creat[ing] their own competence", 62 the judiciary can limit its own role to allow detrimentally affected people and communities to be involved in a process of dialogue with government officials. This is potentially empowering of civil society organisations and representative activist groups. Constitutionalisation, therefore, need not result in a "constitutional gag" and/or a "foreclosure of issues"63 as argued by opponents of constitutional social rights, but can proactively complement and supplement equality mainstreaming by placing an emphasis on dialogue. A combination of both

58 C Fabre, Social Rights under the Constitution: Government and the decent life (Oxford: Clarendon Press 2000), p. 178.

59 M Tushnet, "Social welfare rights and the forms of judicial review" (2003-04) 82 Texas Law Review 1894-919, at 1901.

60 A Nolan, B Porter and M Langford, "The justiciability of social and economic rights: an updated appraisal", prepared for the Human Rights Consortium, Belfast, November 2005, p. 5 (on file with the authors).

61 K Asmal, "Designing a Bill of Rights for a diverse society", speech to Chatham House, London, 26 September 2007, British Irish Rights Watch, available at www.birw.org/BOR\%2010.html.

62 P Macklem and C Scott, "Constitutional ropes of sand or justiciable guarantees?” (1992) 141 University of Pennsylvania Law Review 1-148, at 35-6.

63 S Holmes, Passions and Constraint: On the theory of liberal democracy (Chicago: University of Chicago Press 1995), pp. 10 and 202; and S Holmes, "Gag rules or the politics of omission" in J Elster and R Slagstad (eds), Constitutionalism and Democracy (Cambridge: Cambridge UP 1988), pp. 19-58. 
constitutionalisation and mainstreaming can, therefore, help contribute to the notion of deliberative and participative democracy referred to earlier.

Viewed in this way, constitutionalisation disputes the merit in traditional steadfast liberal adherence to the benefits of parliamentary sovereignty. Constitutionalising can make for a more dynamic and vibrant interaction between organs and aspects of governance, which, in itself, is potentially transformative and facilitative of transition from an unequal to a more just and equal society. This may be an uncomfortable conclusion for those of the "democratic positivist" 64 school of thought. However, on the basis that traditional and historic assumptions about equality have manifestly not delivered an equal society, locally or globally, it is time to reconceptualise the notion of constitutionalisation so the focus is not on the traditional doctrine of parliamentary sovereignty. Rather, constitutionalisation should be conducted more fully to emphasise and establish the responsibilities of governments in their relationship with citizens and to help ensure that those who most need protection and the facilitation of their active agency are not denied their most basic rights: dignity and equality including "equality of citizenship". Characterised in this way, constitutionalisation is about enhancing democracy and accountability as courts, in their role as arbiter of the rights-based relationship between government and citizens, can assist in a functional and concrete way in ensuring the needs of the most disadvantaged citizens are met. For those who are not convinced that courts are the most appropriate institution to adjudicate socioeconomic rights claims, we argue that we can and should move beyond the highly polarised and increasingly stale debate as to which institution is best - be it parliament or court - that has heretofore dominated the discourse on constitutionalisation. ${ }^{65}$ Rather, as Porter suggests, the debate should be about exploring and creatively investigating how courts might usefully enhance capacity to deliver results in this area, and/or how courts might be assisted by other institutional actors including parliament in performing an adjudicative role ${ }^{66}$ which enhances the democratic experience of all concerned.

\section{Strengths and weaknesses of mainstreaming and constitutionalisation as tools for delivering equality}

The foregoing discussion posits equality mainstreaming and the constitutionalisation of socio-economic rights as viable tools to address inequality. However, this is no unqualified panacean claim. Both tools bring their own conundrums and challenges. We have not sought in this article to provide a full overview of equality mainstreaming and s. 75 . Readers

64 M Hunt, "Reshaping constitutionalism" in Morison et al., Judges, n. 8 above, p. 468.

65 This debate has been referred to by Hunt as "democratic positivism" and "liberal constitutionalism": ibid., p. 68. As noted earlier, Jeremy Waldron and Robert Dahl are "democratic positivists" as they are concerned with courts having the final say on the meaning of rights and having the power of judicial review. "Liberal constitutionalists" include Ronald Dworkin who argues that courts should be the final arbiters of rights. See generally, R Dworkin, Taking Rights Seriously (Cambridge, Mass: Harvard UP 1977); Freedom's Law (Cambridge, Mass: Harvard UP 1996); Law's Empire (London: Fontana Press 1986). For some of the most influential essays on the continuing debate between constitutionalism and democracy, see R Bellamy (ed.), The International Library of Essays in Law and Legal Theory: Constitutionalism and democracy (Aldershot: Ashgate 2009).

66 Nolan et al., "The justiciability”, n. 60 above. 
can avail of fuller description and critique in a number of previous reports/reviews. ${ }^{67}$ In this paper, we seek to concentrate on only those features underpinning s. 75 that have been particularly problematic.

Writing in 2000, Livingstone, Osborne, Wilford and Wilson stated that s. 75:

is unable to address the substance of inequality rather than the processes in which public authorities engage. It will not matter if a range of inequalities in Northern Ireland remain [sic] entirely unchanged by [s.] 75 - as, in large measure, they probably will. Equality schemes will still be accepted by the Equality Commission or, if passed upwards, by the Northern Ireland Secretary, as long as public bodies go through the requirements of schedule 9 of the act [sic]. Schedule $9 \ldots$ focuses entirely on the processes on which compliance is seen to depend. No substantive achievements are required at all .. . It is an administrative-bureaucratic instrument, rather than being policy-driven, and considerations of effectiveness and efficiency have hardly figured in its elaboration. ${ }^{68}$

Unfortunately, 10 years later, s. 75 is still primarily procedural in nature with little evidence showing that it produces much in the way of substantive results. In this regard, McLaughlin and Faris found that widespread "formal/thin" 69 compliance with the statutory equality duties has been achieved, in stark contrast to the almost complete implementation failure of the duty's non-statutory precursor, the Policy Appraisal and Fair Treatment (PAFT) guidelines. ${ }^{70}$ However, "thick" compliance, which is defined as that which engages with both the spirit and the letter of the law, has been less forthcoming. ${ }^{71}$ This finding is also supported by Obsorne:

While there has been effective compliance in the fulfilling of the procedural requirements of the statutory obligations [thin compliance], something public officials are comfortable with, there is little evidence as yet that public organisations are taking mainstreaming to mean the wholesale reconsideration of how things are done both internally and in terms of how they formulate and deliver policy. ${ }^{72}$

The compliance conundrum of thin being too easy and thick being too difficult accounts for much of the disillusionment with the statutory duty which developed within

67 A number of reports examining the operation of s. 75 have been carried out both by the ECNI and by several writers: ECNI, "Section 75", n. 11 above; Faris and E McLaughlin, The Section 75 Equality Duty, n. 24 above; Chaney and Rees, The Statutory Equality Duty, n. 34 above; McCrudden, Mainstreaming Equality, n. 24 above; A Trotman, Assessing the Role of OFMDFM in Contributing to the Effectiveness of Section 75 of the Northern Ireland Act (Belfast: ECNI 2007), available at www.equalityni.org/archive/pdf/ OFMDFMNIOFinRpt03071gramamend.pdf; B Dickson and C Harvey, An Assessment of the Role of the Equality Commission in the Effectiveness of Section 75 of the Northern Ireland Act 1998 (Belfast: ECNI 2006), available at http://www.equalityni.org/archive/pdf/CommissRole011206.pdf; Simon Bridge Associates, An Assessment of the Effectiveness of Section 75 of the Northern Ireland Act 1998 in Terms of the Development and Implementation of Public Policy (Belfast: ECNI 2007), available at www.equalityni.org/archive/pdf/ FinalRptImpactsPolicySimonBridge.pdf.

68 R Osborne, S Livingstone, R Wilford and R Wilson, Equality and Institutional Change in Northern Ireland, Report to the ESRC (London: ESRC 2000), p. 5.

69 Formal or thin compliance is defined as that which obeys the letter of the law.

70 PAFT guidelines were discretionary and were a non-statutory way of trying to secure equality outcomes. However, due to their discretionary nature, they were extensively criticised as being ineffective. See R Osbourne, R Cormack and S Shortall, "The implementation of the policy, appraisal and fair treatment guidelines" in E McLaughlin and P Quirk (eds), Policy Aspects of Employment Equality (Belfast: SACHR 1996).

71 Faris and McLaughlin, The Section 75 Equality Duty, n. 24 above.

72 R Osborne, "Progressing the equality agenda in Northern Ireland" (2003) 32 Journal of Social Policy 339-60, at 365 . 
civil society over the 2000 to 2004 period. This disillusionment seems to have extended beyond 2004 to 2008, as noted by the ECNI's final report: "The majority of the organisations (the voluntary and community sectors) indicated that in their experience any representations made to the public authorities have not affected a change."73

The above findings are disappointing as equality mainstreaming process has the potential to involve groups in influencing governmental decision making with its emphasis on consultation and participation. In fact the facilitation of inclusive process and fair exchange of views is exactly why equality mainstreaming should and could be so important in ensuring substantive equality as it allows the effects of policies and laws to be benchmarked against the experience of affected groups and individuals.

Consultees now have access to organisations and individuals in a way that would not have been facilitated before the introduction of s. 75 . Networks and consultative forums have been established to facilitate debate between various stakeholders. There has in theory been a significant development in what one might term the "civic dialogue" aspect of s. 75 .

However, the reality paints a different story. As the above quotation from the ECNI's final report shows, the inclusion of minorities and the disadvantaged within decisionmaking processes does not necessarily change the substance of the decisions made nor lead to reductions in inequality and increases in equality for two reasons. First, attainment of effective rather than token inclusion is far from easy. Analyses of social partnership and other forms of participative governance have shown how a wealth of sub-processes act to limit the impact of the inclusion of the disadvantaged and to maintain privileged power relations and the status quo. These various processes can turn apparently democratic forms of governance into charades. ${ }^{74}$

Secondly, as noted above, the restriction of mainstreaming to process rather than content means it has to be parasitical on specific policies. In order to achieve fair or meaningful equality of opportunity, it is necessary to build bridges between negative and positive equality duties, that is between freedom from unlawful discrimination on the one hand, and the enjoyment of the social minimum of socio-economic rights on the other. ${ }^{75}$ Such rights are necessary if all citizens are to have the basic opportunity of developing the capabilities necessary for meaningful participation in the competition for advantage. In other words, rather than adopting the timid notion of equality of opportunity discussed earlier and which paradoxically is manifested in the s. 75 emphasis on procedural requirements, more emphasis should be placed on the robust understanding of equality of opportunity leading to equality of results. Given that this has not been done in the most innovative legislative attempt to secure equality to date, it is clear that mainstreaming equality alone is insufficient for the achievement of substantive equality.

This is where constitutional protection and adjudication of socio-economic rights could potentially play a role. Framing such rights in a way which places more emphasis on engaging with the effects of government policies and takes into consideration broader historical, social and economic factors, allows the reality to be addressed that certain groups are more vulnerable than others. In such circumstances, the state may be required to take positive action even if this entails expenditure of resources and/or to ensure that those who

73 ECNI, "Section 75", n. 11 above, p. 66.

74 E McLaughlin, Equality and Social Policy: Towards a concept and practice of peaceful policy, Equality Project Working Paper No 11 (2005), available at www.qub.ac.uk/sites/EqualitySocialInclusionInIreland-HomePage/ ProjectPublications/.

75 D Millar, "What is social justice?" in N Pearce and W Paxton (eds), Social Justice: Building a fairer Britain (London: IPPR \& Politicos 2005). 
are affected by its policies are consulted and engaged. The extensive protection and judicial enforcement of social and economic rights in the post-apartheid South African Constitution make it appropriate to draw upon this experience to test the validity or otherwise of our arguments.

It is important to remember at the outset that, as is the case in Northern Ireland, the inclusion of socio-economic rights in the South African Constitution was not uncontroversial. ${ }^{76}$ Given the inequalities and the systemic discrimination and injustices of the apartheid era, ${ }^{77}$ the South African Constitutional Court (SACC) noted that South Africa had "great experience in constitutionalising inequality". ${ }^{78}$ However, despite this or arguably due to this "great experience", the Final Constitution which was adopted in $1996,{ }^{79}$ includes an extensive list of social and economic rights. ${ }^{80}$ The South African Constitution therefore affirms the indivisibility and interdependence of all rights, a fundamental principle recognised in international law. ${ }^{81}$ Some of these rights, such as the right to basic education and the right not to be refused emergency medical treatment, are directly enforceable like civil and political rights. Other rights including the right to have access to adequate housing, to health care services, sufficient food and water and social security are referred to as "access rights". The extent of the state's positive duties regarding these rights is qualified by three key elements: (a) the obligation to "take reasonable legislative and other measures"; (b) "to achieve the progressive realisation of these rights"; and (c) "within available resources". ${ }^{82}$ As stated earlier, these qualifications take into consideration some of the concerns about making socio-economic rights justiciable. Indeed, some social activists and academics argue that the SACC has shown too much deference to the state and has adopted

76 D Davis, "The case against the inclusion of socio-economic demands in a Bill of Rights except as directive principles" (1992) 8 South African Journal on Human Rights 475-90.

77 Chaskalson described the apartheid era as a "wicked system of law". See A Chaskalson, "From wickedness to equality: the moral transformation of South African law" (2003) 1(4) International Journal of Constitutional Law 590-609.

78 Prinsloov Van Der Linde and Another 1997 (6) BCLR 756, at para. 20 (CC).

79 As part of the negotiated settlement, South Africa had an Interim Constitution for two years which came into effect in April 1994, after the first democratic elections. The Interim Constitution was drafted under the auspices of the Convention for a Democratic South Africa which was dominated by the two main political organisations, the African National Congress (an anti-apartheid group) and the National Party. The Interim Constitution was agreed upon and passed by the old parliament as the Constitution of the Republic of South Africa 200 of 1993. A Final Constitution was then adopted in 1996 (the Constitution of the Republic of South Africa 1996) and came into force in February 1997. The Final Constitution was drafted by an elected Constitutional Assembly during the tenure of the Interim Constitution. Space constraints preclude a discussion on how the controversy over socio-economic rights was overcome. For an excellent analysis of the drafting of these and other rights in both constitutions, see H Ebrahim, The Soul of a Nation: Constitution-making in South Africa (Cape Town: Oxford UP 1998).

80 Such rights include the right to adequate housing (s. 26), the right to have access to health services, food, water and social security (s. 27) and guaranteeing the right to education (s. 29).

81 Article 22 of the Universal Declaration of Human Rights 1948 states that rights to economic, social and cultural rights are indispensable to human "dignity and the free development of personality". See also the preambles to both the International Covenant on Civil and Political Rights and the ICESCR respectively: "Recognizing that, in accordance with the Universal Declaration of Human Rights, the ideal of free human beings enjoying civil and political freedom and freedom from fear and want can be achieved only if conditions are created whereby everyone may enjoy his civil and political rights, as well as his economic, social and cultural rights."; "Recognizing that, in accordance with the Universal Declaration of Human Rights, the ideal of free human beings enjoying civil and political freedom and freedom from fear and want can be achieved only if conditions are created whereby everyone may enjoy his economic, social and cultural rights, as well as his civil and political rights." The indivisibility of rights was also reaffirmed by the Vienna Declaration and Programme for Action (1993), para. 5: "All Human Rights are universal, indivisible, interdependent and interrelated."

82 Ss 24 to 29 of the Final Constitution 1996. 
interpretative strategies that are designed to give too much discretion to government in implementing social rights. 83 These interpretative strategies have resulted from the SACC using the "reasonableness test". In that regard, the potential of constitutionalisation of socio-economic rights to help deliver substantive equality may be limited, something which will now be explored through the examination of a necessarily select list of South African socio-economic cases.

Unsurprisingly, given that under apartheid the white minority enjoyed better access to housing, health care, education and other services than the black majority, ${ }^{84}$ the SACC has heard a series of cases concerning housing and forced evictions. The case of Occupiers of 51 Olivia Road, Berea Township and 197 Main Street, Johannesburg v City of Johannesburg and Others 85 (hereinafter the Berea case) is an apt illustration of how a legal approach can help supplement a non-legal approach. Briefly, the case concerned the City of Johannesburg applying for an order of eviction in respect of 400 residents (including men, women and children) of inner-city buildings on the basis that the living conditions were both unsafe and unhealthy. As no alternative accommodation had been offered, the evictions would most likely result in the evictees being homeless. They therefore resisted the eviction claiming that the city's housing policy violated s. 26 of the constitution - the right to adequate housing. The case was eventually appealed to the SACC. Adopting a creative and innovative approach, before the SACC heard the case, it ordered both parties "to engage with each other in a proactive and honest endeavour to find mutually acceptable solutions". ${ }^{86}$ Following this court order, an agreement was reached between both parties which resulted in over 400 residents being temporarily relocated without forced eviction. Furthermore, it has been reported that the new buildings are less hazardous as they have water, electricity and sanitation facilities. ${ }^{87}$

Unlike the tokenistic approach to consultation adopted in the Northern Ireland incarnation of equality mainstreaming, the Berea case shows how dialogue and engagement with the affected communities arising from the judicial enforcement and implementation of socio-economic rights resulted in tangible benefits for the rightsholders. With the emphasis on participation, the concept of deliberative/participatory democracy, referred to earlier, has been brought one step forward by constitutionalisation and court enforcement of socio-economic rights.

The judgment is also a landmark ruling as it shows that the courts can utilise nonadjudicatory remedies, to ensure that the state fulfils its constitutional obligations, this without encroaching too much on the legislature and/or the executive. In so doing, this approach helps to ensure that the formulation and articulation of policies and law are not the sole preserve of a particular branch of government or other power elite within society. Rather, through the SACC's encouragement of dialogue between the parties, the SACC's

83 M Pieterse, "Possibilities in the domestic enforcement of social rights: contemplating the South African Experience" (2004) 26(4) Human Rights Quarterly 882-905; and S Liebenberg, Needs, Rights and Transformation: Adjudicating social rights, Working Paper No. 8 (New York: Center for Human Rights and Global Justice, New York Law School 2005), available at www.nyuhr.org/docs/wp/Liebenberg\% $\% 20-\% 20$ Needs, $\% 20$ Rights $\% 20$ and $\% 20$ Transformation.pdf.

84 K Govender, "Attempting to achieve substantive equality in one of the most unequal societies in the world: the South African experience" (paper presented at NICEM's Annual Human Rights and Equality Conference, Belfast, October 2005), p. 5 (on file with the authors).

85 (24/07) [2008] ZACC 1; 2008 (3) SA 208 (CC); 2008 (5) BCLR 475 (CC) (19 February 2008).

86 Ibid., para. 12.

87 H Moray et al., "Victory for engagement in relocation from San Jose", Business Day, 9 September 2008, quoted by C Mbazira, Litigating Socio-Economic Rights in South Africa: A choice between corrective and distributive justice (Pretoria: Pretoria University Law Press 2009), p. 176. 
approach to constitutional rights adjudication usefully remedied socio-economic inequalities by ensuring that the process of furthering equality is a "shared project". 88 Focusing on rightsholders and what is at stake for them as far as dignity and equality are concerned diminishes the worry around which organ of government should deliver. This shift in focus has had two positive results. One, it has helped to ensure that rather than closing down the debate about rights or hiving them off to a "rarefied court", 89 constitutionalisation can help bridge the gap between the government and the governed, thereby reducing the myths that usually come with the traditional understanding of constitutionalisation. Secondly, as Christiansen eloquently states, when a court order supports the work of popular movements, non-governmental organisations and poverty activists, it helps to support the "further realization of social justice" with limited judicial involvement and "very beneficially, coordinates cause lawyering and broader popular movement". 90

Arguably, one of the reasons why participation was more effective in the Berea case than under equality mainstreaming as played out in Northern Ireland is the fact that, following a court order, the state authorities were constitutionally required to consult and negotiate with the affected communities. This kind of gravitas is not achievable by virtue of the enforcement mechanisms underpinning s. 75. As noted earlier, one of the unique features of s. 75 is that the remedy for failure to mainstream adequately is not through litigation but via the political domain. Before a complaint enters the political arena, the primary body responsible for the enforcement and implementation of s. 75 is the ECNI. The ECNI can initiate two types of investigations: an investigation of a complaint by an individual who claims to have been directly affected by the failure of a public authority to comply with its approved equality scheme ${ }^{91}$ and an investigation initiated by the ECNI where it believes that a public authority may have failed to comply with its approved equality scheme. ${ }^{92}$

One organisation, the CLC, which has taken complaints to the ECNI regarding the introduction of pieces of legislation, found the process of the ECNI's intervention to be "unduly long and drawn out". 93 While the CLC opines that the majority of delays were and continue to be caused by procedural matters, a point of concern is that these "delays have often resulted in loss of any remedy where there is a suspected breach of an approved Equality Scheme". ${ }^{94}$ Even when there has been a breach of s. 75 , there are extremely limited sanctions following the outcome of an investigation. These result in either a referral to the Secretary of State or laying the report before the Northern Ireland Assembly. The latter happens if the public authority is a government department. The ECNI views itself as "lack[ing] teeth" 95 in both instances. As it is "given no power to direct a public authority to take any action . . . the Commission appears fairly powerless in this area". 96 This powerlessness has been further exacerbated by the High Court holding that the ECNI had erred in its handling of a complaint by the CLC which challenged the introduction of AntiSocial Behaviour Orders (ASBOs) in Northern Ireland alleging a breach of the Northern

88 C Harvey, "Protecting the marginalized" in Morison et al., Judges, n. 8 above, p. 530.

89 F Klug, "The long road to human rights compliance” (2006) 57(1) NILQ 186-204, at 201.

90 E Christiansen, "Using constitutional adjudication to remedy socio-economic injustice: comparative lesson from South Africa" (2008) 13 Journal of International Law and Foreign Affairs 369-405, at 399.

91 Sch. 9, para. 10 of the 1998 Act

92 Sch. 9, para. 11 of the 1998 Act. The ECNI has completed eight such investigations. See ECNI, "Section 75", n. 11 above, p. 54.

93 CLC, "Response", n. 39 above, p. 9.

94 Ibid.

95 ECNI, "Section 75 ", n. 11 above, p. 55.

96 Dickson and Harvey, Assessing the Role of the Equality Commission, n. 67 above, pp. 96-7. 
Ireland Office's (NIO) equality scheme. ${ }^{97}$ The Court held that the CLC, was not "directly affected" by a breach of an equality scheme by the NIO. ${ }^{98}$ This restrictive interpretation has important implications for the meaningful and effective implementation of s. 75 as representative bodies are not permitted to make a complaint on behalf of their client base. This, as the CLC states:

undermines the effectiveness of the Commission's complaints procedures and consequently the effectiveness of section 75 in its entirety. We do not believe that it was the intention of section 75 that paragraph 10 complaints could only be taken by individuals. This is particularly the case given the lack of public knowledge of section 75 , the complexity of the processes which surround it and the vulnerability of some of the section 75 categories, such as children and young people. ${ }^{99}$

The effectiveness of s. 75 is also undermined through the fact that not all policies are subject to screening. As indicated earlier, public authorities can "screen out" those policies and practices which, in their opinion, do not need to be made impact-assessed. Furthermore, there has been a generalised attempt by the Northern Ireland government departments to exempt what they describe as "high level policy"100 from the demands of s. 75. This has had obvious implications for the legislation to realise fully its potential. ${ }^{101}$ The fact that these policies tend to have the greatest impact on the Northern Ireland public is precisely the reason why these very policies need to be subject to more fulsome scrutiny and regulation. The ECNI has stated it will provide advice to government departments to promote clarity on an approach to EQIA regarding high-level policies. ${ }^{102}$ While we welcome this long overdue advice, arguably, if those senior "high-level" decision makers were required to give well-reasoned, public justification for their decisions, as would happen if rights such as economic and social rights were to be constitutionalised, this could potentially serve to enhance public power accountability as well as more fully protecting the most vulnerable from unjust and unfair policies.

The South African Grootboom case ${ }^{103}$ is another case with strong resonance for constitutionalising socio-economic rights in Northern Ireland. This concerned the right to housing for squatters. The SACC held that the government had failed to take reasonable legislative and other measures, within its available resources, to achieve the progressive realisation of the constitutional right to have access to adequate housing. The government's housing policy in this respect was "unreasonable" and therefore unconstitutional. Close scrutiny of the government's housing programme resulted in the government being restrained from issuing eviction orders. Thus, the SACC's judgment helped prevent largescale homelessness. That said, compliance with the judgment was far from efficient as, four years after the judgment, the living conditions of members of the plaintiff class were

97 In the Matter of an Application for Judicial Review by Peter Neill [2006] NIQB 66.

98 The ECNI has noted that the court's judgment has influenced the ECNI's interpretation of "directly affected". ECNI, "Section 75", n. 11 above, p. 54.

99 CLC, "Response", n. 39 above, p. 10.

100 High-level policies, such as the development of government's budget and priorities, are those which tend to have the greatest impact on the Northern Ireland populace.

101 The ECNI has noted that it "will as a matter of priority, provide targeted and detailed advice across government departments to ensure clarity on equality impact assessment of high level policies". ECNI, "Section 75", n. 11 above, p. 39.

102 Ibid., p. 45.

103 South Africa v Grootboom 2001 (1) SA 46 (CC). Other seminal eviction cases are President of South Africa \& Others v Modderklip Boerdery \& Others, Constitutional Court of South Africa, Case CCT 20/04, unreported judgment of 13 May 2005 and Port Elizabeth Municipality v Various Occupiers (1) 2005 SA 217 (CC). 
similar to those prior to the judgment. ${ }^{104}$ Furthermore, the judgment made no reference to the necessity to subject the housing policy to further review. As one report stated: "we won the championship, but where's the trophy?" 105 On this view, a pyrrhic victory was achieved. This shows that, even where socio-economic rights are judicially enforceable, there are still numerous challenges in securing these rights in practice - an area where effective equality mainstreaming processes could clearly assist.

A later South African case, involving the right to access health care (the TAC case), ${ }^{106}$ dealt with overcoming some of these challenges. Following a searching analysis of the government's justification in refusing to provide a drug, nevirapine, that would prevent mother-to-child transmission of AIDS in public hospitals, the SACC rejected the government's reasons as unreasonable and unconstitutional. Unlike a previous health care case, the Soobramoney case, ${ }^{107}$ the SACC adopted a more robust and less deferential approach and held that resources were available.

In the TAC case, the SACC's orders ${ }^{108}$ had a direct and immediate impact on the enjoyment of socio-economic rights by hugely vulnerable people. As such it is a stellar example of how constitutionalisation can help benefit the quality of lives of the most marginalised. As Geoff Budlender states:

Many people see the TAC case as a model in a way which has a real impact on people's lives. The TAC case has literally saved the lives of very many thousands of kids. That destroys the arguments of those who say these are just paper rights and have no value. ${ }^{109}$

However, a less welcome aspect of the judgment was the SACC's acknowledgment that s. $27(1)^{110}$ would never "give rise to a self-standing and independent positive right". ${ }^{111}$ This aspect of the judgment has been criticised as causing the "most damage to the vindication of social rights". ${ }^{112}$ To a certain extent, while we understand why some would find this particular aspect of the judgment problematic, the SACC is rightly concerned not to cross

104 M Tushnet, "Social welfare rights", n. 59 above, at 1905.

105 Centre on Housing Rights and Evictions, Litigating Economic, Social and Cultural Rights: Achievements, challenges and strategies (Geneva: COHRE 2003), p. 9, available at www.cohre.org/library/Litigating $\% 20$ ESCR $\%$ 20Report.pdf.

106 TAC (Treatment Action Campaign) v Ministers of Health 2002 (10) BCLR 1033 (CC).

107 Soobramoney v Minister of Health (Kwazulu-Natal) (CCT32/97) 1998 (1) SA 765 (CC). This case concerned a terminally ill diabetic who was denied access to a renal dialysis machine that would have prolonged his life. The hospital had adopted a policy where terminally ill patients were given lower priority than those who had greater chances of surviving. The applicant challenged this policy arguing that his right to health and emergency medical treatment had been violated. Where resources are scarce, the SACC held that the government policy was consistent with the constitutional right to health care and emergency treatment.

108 The orders included directing the government to remove the restrictions on the distribution of the drug to extend the nevirapine programme throughout the entire country and the state was obliged to make provision if necessary for counsellors in hospitals and clinics where the programme was not in place: TAC (Treatment Action Campaign) v Ministers of Health 2002 (10) BCLR 1033 (CC), para. 765.

109 Interview with Geoff Budlender in Centre on Housing Rights and Evictions, Litigating Economic, Social and Cultural Rights, n. 105 above, p. 98.

110 S. 27(1) reads: "Everyone has the right to have access to (a) health care services, including reproductive health care; (b) sufficient food and water; and (c) social security, including, if they are unable to support themselves and their dependants, appropriate social assistance."

111 TAC (Treatment Action Campaign) v Ministers of Health 2002 (10) BCLR 1033 (CC), para. 39.

112 M Pieterse, "Possibilities", n. 83 above, at 898. Pieterse and other writers have debated the SACC's rejection of the "minimum core standard" which has developed in international law. See D Davis, "Adjudicating the socio-economic rights in the South African Constitution: towards 'deference lite'?" (2006) 22 South African Journal on Human Rights 301-27; and Liebenberg, Needs, Rights and Transformation, n. 83 above. 
the constitutional Rubicon when it comes to dealing with delicate and sensitive choices found in socio-economic jurisprudence. That said, it is important that courts do not, as the Canadian Supreme Court has stated:

carry judicial deference to the point of accepting Parliament's view simply on the basis that the problem is serious and the solution difficult... [to do so] would be to diminish the role of the courts in the constitutional process and to weaken the structure of rights upon which our constitution and our nation is founded. ${ }^{113}$

Although there is risk that if courts do not adopt a robust approach and are deferential to the legislature, it may well "diminish the role of courts in the constitutional process", as the South African experience has shown, the process of constitutionalisation has at least afforded victims a forum for a hearing and potentially a remedy when a right is violated. This finding is, of course, qualified in that sometimes remedies do not necessarily result in the immediate amelioration of socio-economic conditions. The fact that socio-economic jurisprudence has produced somewhat of a mixed bag in these terms simply reflects the reality that judges are just as capable of making narrowly restrictive decisions (such as Soobramoney) as progressive ones (such as TAC and Berea) in the complex area of social and economic rights. This is no more than a trend which is evident in all aspects of the law and does not, therefore, form a legitimate basis for rejecting the role that constitutionalisation and the subsequent adjudication of socio-economic rights can play in advancing equality.

\section{THE PROPOSED CONSTITUTIONALISATION OF SOCIAL AND ECONOMIC RIGHTS IN A BILL OF RIgHTS FOR NORTHERN IRELAND}

There are still some sectors of opinion, especially within the political arena, strongly opposed to the constitutionalisation of socio-economic rights in a Bill of Rights for Northern Ireland. Interestingly, this appears less linked to the issues explored above and more to a continuing allegiance to the "democratic positivism" school of thought discussed earlier.

The Northern Ireland Human Rights Commission (NIHRC), the statutory body responsible for consulting and advising the British government on the content of a Bill of Rights for Northern Ireland, finally submitted its advice to the Secretary of State for Northern Ireland on 10 December 2008. ${ }^{114}$ Within this advice, the NIHRC has proposed an extensive list of socio-economic rights. ${ }^{115}$ This decision has not been uncontroversial. ${ }^{116}$ Suffice, for the purposes of this paper, to state that some of the controversy has arisen from the ambiguous nature and lack of guidance of the Agreement and s. 69(7) of the 1998 Act which simply states:

The new Northern Ireland Human Rights Commission will be invited to consult and to advise on the scope for defining, in Westminster legislation, rights supplementary to those in the European Convention on Human Rights, to reflect the particular circumstances of Northern Ireland, drawing as appropriate on international instruments and experience. These additional rights to reflect the principles of mutual respect for the identity and ethos of both communities and parity of esteem, and - taken together with the ECHR - to constitute a Bill

113 RJR-MacDonald Inc. v Canada (AG) [1995] 3 SCR 199, para. 136.

114 NIHRC, “A Bill of Rights", n. 5 above.

115 The right to health, the right to an adequate standard of living, the right to accommodation, the right to work, environmental rights, the right to social security: ibid., pp. 44-50.

116 For an analysis of the controversy surrounding the inclusion of socio-economic rights from the period 2000-05, see the report by S Livingstone, R Murray and A Smith, Evaluating the Effectiveness of National Human Rights Institutions: The Northern Ireland Human Rights Commission with comparisons from South Africa (London: Nuffield Foundation, February 2005), pp. 110-12. 
of Rights for Northern Ireland. Among these issues for consideration by the Commission will be:

- the formulation of a general obligation on government and public bodies fully to respect, on the basis of equality of treatment, the identity and ethos of both communities in Northern Ireland; and

- a clear formulation of the rights not to be discriminated against and to equality of opportunity in both the public and private sectors. ${ }^{117}$

The Bill of Rights consultation process has been dogged in respect of the interpretation of what precisely the Agreement means. One of the most problematic phrases has been "the particular circumstances of Northern Ireland"118 and the lack of consensus both within and outside the NIHRC on its exact meaning has taken its toll on the constructiveness of the project undertaken. In 2003, a former NIHRC commissioner noted: "I wouldn't say there is agreement on it . . . I think we all have different understandings or conceptions of what that is about." 119 A number of years later, there still seems to be "different understandings or conceptions". This is aptly illustrated as the two then commissioners (Lady Daphne Trimble and Jonathan Bell) who dissented from the NIHRC's final Bill of Rights advice opined that, by including socio-economic rights alongside other rights and issues, the NIHRC had gone beyond its remit. ${ }^{120}$ The recent debate in the Northern Ireland Assembly ${ }^{121}$ is also indicative that some politicians, especially from the Unionist political tradition, oppose the NIHRC's advice, arguing that it has exceeded its remit by including socio-economic rights: "It [the NIHRC] was not mandated to devise a new bill of rights or to change our socio-economic context through the creation of numerous new rights." 122 Supporting this argument, another Unionist

117 Strand 3, para. 4 of the Human Rights section of the Agreement.

118 For an overall analysis of the different elements of the NIHRC's mandate and other problematic phrases of the Agreement on the Bill of Rights, see A Smith, "The drafting process of a Bill of Rights for Northern Ireland" (2004) Public Law 526-36.

119 Interview with a former commissioner, April 2003.

120 Submitting evidence to the Northern Ireland Affairs Committee (NIAC), Lady Trimble in response to a question that the NIHRC had gone beyond the proposals in the Agreement, stated: "I do think that that is the case. If you look at the proposals around the socio-economic rights, the areas that those are addressing are by and large common societal problems right across the UK; if you look at housing, that is a problem right across the UK, it is not specific to Northern Ireland; ditto the environment, and rights to social security. So it seems to me to be rather difficult to come up with a proposal that there should be rights around these areas in Northern Ireland when there are not similar rights in the rest of the UK.." Minutes of Evidence Taken before the NIAC, A Bill of Rights for Northern Ireland, House of Commons, Lady Trimble, available at www.publications.parliament.uk/pa/cm200809/cmselect/cmniaf/uc360-ii/uc36002.htm. The NIAC is conducting a short inquiry into the process towards a Bill of Rights for Northern Ireland: see www.parliament.uk/parliamentary_committees/northern_ireland_affairs/niac0809pn15.cfm. In March 2010, Lady Daphne Trimble resigned from the NIHRC to take part in the recent parliamentary election and Jonathan Bell also resigned to take up his MLA (Member of the Assembly) position.

121 It is interesting to note that the Northern Ireland Assembly had a similar debate in 2001 when politicians were divided as to whether or not the NIHRC had exceeded its remit. Like the 2009 debate, the Unionist politicians argued that socio-economic issues should not have been included in the $2001 \mathrm{draft}$ Bill of Rights document (NIHRC, "Making a Bill of Rights", n. 5 above) whereas the Nationalist political parties were in favour of such rights. See Northern Ireland Assembly, Official Report (2001-02), 25 September 2001.

122 Northern Ireland Assembly, Mr Kennedy, Private Members' Business on the NIHRC, 3 November 2009, at 79, available at www.niassembly.gov.uk/record/reports2009/091103.pdf. The two commissioners who dissented from the NIHRC's final advice represent the two main Unionist political parties: Lady Trimble (the Ulster Unionist Party) and Jonathan Bell (the Democratic Unionist Party). 
politician stated, "[the words of the phrase "the particular circumstances of Northern Ireland'] do not open the door to economic, social and cultural rights". ${ }^{123}$

The NIO's long-awaited consultation on the NIHRC's advice also shares this view. The consultation paper states that socio-economic rights do not relate to Northern Ireland specifically but, if they are to be considered, should be addressed not in terms of a regional debate but in a national discussion on a possible UK Bill of Rights and Responsibilities which was launched by the government's Green Paper in March 2009.124 In this paper, the government's position on socio-economic rights is very clear. Decision making in this regard should remain with Parliament, not the courts, as this would impinge "on the principle of democratic accountability" 125 as well as the separation of powers between the three branches of government (the judiciary, the executive and the legislature). The government's refusal to ratify the Optional Protocol to the International Covenant on Economic, Social and Cultural Rights (ICESCR) is also a further indicator of its opposition to making socio-economic rights justiciable.

We find both the government's and the Unionist arguments problematic for several reasons. Firstly, their opposition to the inclusion of socio-economic rights ignores the overwhelming cross-community support in Northern Ireland for their inclusion. ${ }^{126}$ Secondly, poverty is without doubt a very particular and increasingly documented feature of "the particular circumstances of Northern Ireland". There is evidence that as a result of the conflict, people in Northern Ireland suffer from high levels of social deprivation, including poor health standards, reduced life expectancy rates and high levels of unemployment. ${ }^{127}$ The Poverty and Social Exclusion Survey for Northern Ireland found "on a mixed measure of income and deprivation, that $37.4 \%$ of children in Northern Ireland live in households experiencing poverty" with, as a further Northern Ireland-specific feature "higher poverty rates . . . to be found in families who define themselves as 'Irish' or 'Catholic". 128 The Northern Ireland Anti-Poverty Network has gone so far as to comment in evidence to the UK Parliamentary Select Committee on Work and Pensions that "child poverty levels in Northern Ireland are a skeleton in the cupboard that has been ignored on a national level". ${ }^{129}$ In fact, having examined evidence on poverty and particularly child poverty in Northern Ireland in 2004, the UK Parliamentary Select Committee on Work and Pensions

123 Northern Ireland Assembly, Miss McIlveen, Private Members' Business on the NIHRC, 3 November 2009, at 79, available at www.niassembly.gov.uk/record/reports2009/091103.pdf. A similar debate also occurred in the Bill of Rights Forum which comprised of civil society and political parties. The forum was set up in December 2006 to assist the NIHRC in providing advice to the British government on a Bill of Rights for Northern Ireland. The forum produced its report to the NIHRC in March 2008, "Final Report: Recommendations to the Northern Ireland Human Rights Commission on a Bill of Rights for Northern Ireland", available at www.billofrightsforum.org/bill_of_rights_final.pdf. For the discussion around socioeconomic rights, see pp. 78-102.

124 Ministry of Justice, Rights and Responsibilities: Developing our constitutional framework (London: MoJ, March 2009), p. 43, available at www.justice.gov.uk/publications/docs/rights-responsibilities.pdf.

125 Ibid.

126 Hanratty notes that " $90 \%$ of people here [Northern Ireland] think that the Bill should protect social and economic rights"; K Hanratty, “Time to get involved”, Fortnight, July/August 2009, p. 8. A number of surveys have been conducted indicating a high level of cross-community support for the inclusion of social and economic rights. See NIHRC, Opinion Poll MRHI, 2004.

127 NIHRC, "Making a Bill of Rights", n. 5 above, p. 84.

128 P Hillyard, G Kelly, E McLaughlin, D Patsios and M Tomlinson, Bare Necessities: Poverty and social exclusion in Northern Ireland (Belfast: Democratic Dialogue 2003), pp. 32 and 46, available at www.ofmdfmni.gov.uk/barenecessities.pdf.

129 Memorandum submitted by the Northern Ireland Anti-Poverty Network to the House of Commons Select Committee on Work and Pensions, September 2003, available at www.publications.parliament.uk/pa/ cm200304/cmselect/cmworpen/85/85we24.htm. 
was strongly of the view, that "special measures [our emphasis] are needed to bring Northern Ireland into line with household income levels in other parts of the UK".130

Research recently conducted by the Committee on the Administration of Justice (CAJ) is also instructive in this regard, with evidence pointing to the fact that poverty indices in the most deprived wards in Belfast actually show an increase in poverty over the past number of years. ${ }^{131}$ A recent report for the Office of First Minister and Deputy First Minister (OFMDFM) highlighted in particular the levels of fuel poverty faced by lone parents, revealing that lone parents in Northern Ireland on average spend 56 per cent of their income on fuel compared with 26 per cent in the rest of Britain. ${ }^{132}$

In 2009, persistent poverty in Northern Ireland was found to be more than double that in Great Britain with the problem of child poverty particularly entrenched and posing even greater challenges than elsewhere in the UK. ${ }^{133}$ Northern Ireland's most disadvantaged children and young people live in communities that face social exclusion and still experience violence that is the legacy of the conflict. Furthermore, according to Horgan and Monteith, disadvantaged young people are at risk of being attracted to paramilitary groups if society does not address their social exclusion.

The corrosive effect that growing up in persistent poverty can have - in particular the evidence that such children are more likely to be suspended or excluded from school and be in trouble with the police - has added significance [our emphasis] in a society emerging from conflict. The interaction of poverty with the legacy of the conflict makes it both more difficult to end high levels of worklessness and more acceptable to use violence, including violence for political ends, than in other parts of the UK and Ireland. This puts the most socially excluded young people at particular risk. ${ }^{134}$

The recent upsurge in dissident republican paramilitary activity demonstrates that this is no mere paper risk. Another knock-on effect of the coincidence of poverty and conflict legacy is inordinately high levels of mental ill health. The Department of Health, Social Services and Public Safety estimates "that prevalence figures for mental health problems are 25\% higher than in England". 135

Even this brief and non-exhaustive overview provides strong evidence that Northern Ireland suffers particularly from certain highly entrenched forms of poverty and the increasingly emerging links between poverty, conflict and the legacy of conflict attest for the need to address socio-economic rights as very firmly linked to the particular circumstances of Northern Ireland. Therefore, to consider socio-economic rights as part of the debate over a UK Bill of Rights, rather than solely concentrating on the Northern Ireland debate as the NIO proposes, is misleading and perturbing for a number of reasons. Firstly, such an approach fails to take account of the above prima facie evidence of the need

130 House of Commons Select Committee on Work and Pensions, Child Poverty in the UK 2nd Report 2003-04 Session (London: The Stationery Office 2004), available at www.publications.parliament.uk/pa/ cm200304/cmselect/cmworpen/85/8502.htm.

131 CAJ, Equality in Northern Ireland: The rhetoric and the reality (Belfast: CAJ 2007), p. 138.

132 P Hillyard and D Patsios, Child Poverty and Differential Rates of Household Inflation (Belfast: OFMDFM 2009), ch.3, available at www.ofmdfmni.gov.uk/child_poverty_and_differential_rates_of_household_inflation2.pdf.

133 G Horgan, Speaking Out Against Poverty: The views and experiences of children and young people in deprived areas of Northern Ireland (Belfast: Save the Children 2009).

134 G Horgan and M Monteith, What can we do to tackle Child Poverty in Northern Ireland? (York: Joseph Rowntree Foundation, November 2009), p. 10, available at www.jrf.org.uk/sites/files/jrf/tackling-child-povertyNorthern-Ireland-summary.pdf.

135 Ibid., p. 9. 
for such rights to be part of a Northern Ireland Bill of Rights. Furthermore, the UK's Green Paper highlights the need to keep the Northern Ireland Bill of Rights discussion/process separate from that of the UK debate: "the Government does not wish the public debate about a UK instrument to detract from the process relating to a potential Bill relating to the particular circumstances of Northern Ireland". ${ }^{136}$ As noted in the introduction to this paper, 10 years after the Agreement, Northern Ireland still does not have a Bill of Rights and, as Justice points out in its recent report on Devolution and Human Rights, merging the two processes/debates may stymie even further what has been a long and at times contentious process. ${ }^{137}$ Not only would this dampen the expectations of the Northern Ireland populace, the British government would also be in breach of its international obligation as it is a requirement under the Agreement to have a Bill of Rights reflecting "the particular circumstances of Northern Ireland". The other guarantor of the Agreement, the Irish government, has also stated that the international obligation of the UK is to implement a Northern Irish Bill of Rights, not a UK Bill of Rights:

Regarding the bill of rights for Northern Ireland, I reiterate the commitment of the Government to ensure the full and effective implementation of all aspects of the Good Friday Agreement and the St Andrews Agreement. In that context, we attach importance to a specific bill of rights for Northern Ireland as envisaged in the Good Friday Agreement. The Government has consistently communicated that position in contacts with the current British Administration and with the Conservative Party Front Bench. ${ }^{138}$

It is the responsibility of both governments to fulfil their commitments under the Agreement. If the British government and/or Irish government fail to do so, it is arguable that both governments are shying away from their duties and are guilty of shirking their responsibility. ${ }^{139}$

Thirdly, the Agreement clearly recognises the need to deal with the economic and social inequalities in Northern Ireland. ${ }^{140}$ Fourthly, both the Committee on Economic, Social and Cultural Rights and the Council of Europe have strongly recommended the inclusion of such rights in a Bill of Rights "without delay". ${ }^{141}$ Finally, as previously discussed, while the

136 Ministry of Justice, Rights and Responsibilities, n. 124 above, para. 4.38.

137 Justice, Devolution and Human Rights (London: Justice, February 2010), p. 22, available at www.justice.org.uk/images/pdfs/Devolution \%20and\%20Human\%20Rights.pdf.

138 Answer of the Taoiseach in response to a question by Deputy Eamon Gilmore, 21 October 2009, Parliamentary Debates, Vol. 692, No. 3, p. 564, available at http://debates.oireachtas.ie/Xml/30/ DAL20091021.PDF.

139 The recent political agreement, the Hillsborough Agreement, states that a working group will be set up and will submit a report by the end of March on any "outstanding issues" from the St Andrews Agreement: the Bill of Rights is one of those "outstanding issues". Within four weeks of the working group's initial report, the First Minister and Deputy First Minister will agree a programme to carry out the working group's agreed outcomes: Agreement at Hillsborough Castle, 5 February 2010, p. 21, available at www.rte.ie/news/2010/ 0205/niagreement.pdf.

140 The Agreement recognises that tackling economic disadvantage and promoting social inclusion are key components of building a lasting peace, p. 19.

141 E/C.12/GBR/CO/5, 22 May 2009 (Concluding Observations), para. 10. See also the committee's previous UK Concluding Observations wherein it stated: "The Committee strongly recommends the inclusion of effective protection for economic, social and cultural rights, consistent with the provisions of the Covenant, in any bill of rights enacted for Northern Ireland." See E/C.12/1/Add.795, June 2002 (Concluding Observations), paras 18, 29 and 37. Similarly, the Council of Europe Experts also recommends the inclusion of socio-economic rights recognising that "economic and social rights assist in promoting social cohesion and stability": Comments by the Council of Europe Experts on certain aspects of a future Bill of Rights for Northern Ireland (Strasbourg 2004), paras 34, 27 and 33, quoted by D Holder, "Why a Bill of Rights for Northern Ireland should include economic and social rights" (2009) 8 NIHRC Review 13. 
separation of powers is a fundamental doctrine, it cannot and should not be used as a bar to making socio-economic rights justiciable. As the South African experience has shown, such rights are justiciable without endangering the separation of powers doctrine. The South African experience has, in fact, been drawn upon by the NIHRC in its formulation as to the progressive realisation of some of the proposed socio-economic rights. In that regard, the NIHRC's advice also reflects international and comparative constitutional law more broadly, acknowledging that such rights cannot always impose immediate obligations on states, thus diffusing some of the knee-jerk angst around the fraught issue of resources allocation. It is, however, vital, as the South African experience has illustrated, that this principle of progressive realisation be used for the effective realisation of socio-economic rights rather than to retard their advancement.

\section{Conclusion}

This article has demonstrated that the answer to the question posed in our introduction "Are equality mainstreaming and the constitutionalisation of socio-economic rights viable tools to address inequality? - is a qualified "yes". Such legal tools will never provide any kind of panacea as both have limitations as well as benefits. However, the use of both tools together can offer an important synergy to advance socio-economic rights in a post-conflict society. How constitutionalising is undertaken, the methodology of equality mainstreaming, and the development of effective underpinning enforcement mechanisms are of particular concern in this regard. As a first step to improving the current situation in Northern Ireland, it is important that the government ensures that the ECNI has sufficient powers to oversee the effective implementation of s. 75 .

While the South African experience has been tempered by some disappointing decisions, constitutionalisation of socio-economic rights and their judicial enforcement can and have helped contribute in making the "deep scars"142 of the legacy of apartheid less visible in South African society. While constitutionalisation and adjudication have not delivered in some cases, it is nonetheless significant that through constitutionalisation of socio-economic rights, the South African government has been prevented from "backsliding"143 on its constitutional obligations and is to some extent being "kept on its toes". ${ }^{144}$ The South African experience also makes it clear that, if socio-economic rights are excluded from a Bill of Rights, "you will be throwing a rope of sand to a drowning man". ${ }^{145}$

Returning to the proposed Bill of Rights for Northern Ireland, the NIO's consultation paper states:

A Bill of Rights which has the support of the people of Northern Ireland could play an important role in underpinning the peace, prosperity and political progress of Northern Ireland by ... . protecting those made vulnerable by the particular circumstances of Northern Ireland. ${ }^{146}$

In disregarding socio-economic rights, the government is not only ignoring the widespread support from all sides of the community in Northern Ireland for the inclusion of such rights, but also advice from various international bodies. The exclusion of socioeconomic rights from a Northern Irish Bill of Rights runs the risk of undermining rather than underpinning prosperity. For this and other reasons, the NIHRC has rejected the

142 Brink v Kitshoff NO 1996 (6) BCLR 752 (CC), para. 40.

143 Interview with Geoff Budlender, n. 109 above, p. 98.

144 Asmal, "Designing a Bill of Rights", n. 61 above, p. 605.

145 Ibid.

146 NIO, "A Bill of Rights", n. 5 above, p. 8. 
NIO's consultation paper, a stance which is strongly endorsed and supported by the authors of this article. ${ }^{147}$ As Northern Ireland embraces yet another stage of the consultation process, ${ }^{148}$ we challenge the Secretary of State to ignore at his peril the views of "those made vulnerable by the particular circumstances of Northern Ireland". It behoves the government to listen to those views and respect these wishes. Failure to do so may result in a Bill of Rights, if it ever in fact comes to fruition, not having the "full support of the people of Northern Ireland". If this is the case, it "will amount to nothing more than a meaningless document consisting of empty political rhetoric". ${ }^{149}$ We sincerely hope that this will not be the case.

147 NIHRC, “A Bill of Rights”, n. 5 above.

148 The NIO's consultation process started on 30 November 2009 and ended on 1 March 2010. The NIHRC has criticised the limited nature of the consultation process as being "inadequate". Ibid., pp. 17-27.

149 M Cowling, "Judges and the protection of human rights in South Africa: articulating the inarticulate premise" (1987) South African Journal on Human Rights 177-201, at 183. 